\title{
ABC's, 123's, and the Golden Rule: The Pacifying Effect of Education on Civil War, 1980-1999
}

\author{
Clayton L. Thyne \\ University of Iowa
}

\begin{abstract}
This study examines two ways by which education might affect the probability of civil war onset. First, educational investment provides a strong signal to the people that the government is attempting to improve their lives, which is apt to lower grievances, even in desperate times. Second, education can generate economic, political, and social stability by giving people tools with which they can resolve disputes peacefully, making them less likely to incur the risks involved in joining a rebellion. This theory is tested by examining the effect of educational expenditures, enrollment levels, and literacy rates on the probability of civil war onset from 1980 through 1999. The results provide evidence for both the grievance and stability arguments, providing strong support for the pacifying effects of education on civil war.
\end{abstract}

Conflict scholars have been increasingly interested in improving our understanding of civil war. This attention is not surprising, given the devastating economic and social consequences of these conflicts. On the economic side, a large literature supports the notion that civil wars have a devastating effect on a country's economy, diverting funds away from social programs, disrupting the flow of economic goods, forcing people to push wealth abroad to protect assets, and significantly slowing overall economic growth. Beyond its harmful economic effects, civil war has a destructive impact on many social indicators. Civil wars have caused over 16.2 million deaths from 1945 through 1999, with the majority of deaths of civilians, and have lasted over 6 years on average (Singer and Small 1994; Cairns 1997; Azam and Hoeffler 2002; Fearon and Laitin 2003). More nuanced findings have indicated that civil wars increase adult mortality, infant mortality, and reduce years of healthy life due to long-term disability (Guha-Sapir and Van Panhuis 2002; Ghobarah et al. 2003; Hoeffler and Reynal-Querol 2003). In addition to physical injury, civil wars have been found to disrupt society by causing massive flights of refugees and by interrupting social programs such as education (Collier et al. 2003; Lai and Thyne forthcoming). Thus, the harmful economic and social effects of civil war show quite clearly why research explaining the onset of civil war is needed.

Author's note: The author would like to thank Sara Mitchell, Brian Lai, Kelly Kadera, Fred Boehmke, James M. Scott, Valerie Thyne, participants in the University of Iowa International Relations Workshop, and three anonymous reviewers for helpful comments on earlier drafts of this paper. Any errors and omissions are the author's responsibility alone. Replication data is available on the author's website. 
This study seeks to extend the body of civil war research by examining how education might affect the probability of civil war onset. ${ }^{1}$ A major objective of this paper is to focus on explanations for civil war that are relevant to policy makers. Moore (1995:130) writes, "Given the consequences [civil] conflicts produce, it is incumbent on social scientists to provide a better understanding of these conflicts so that we may put policy makers in a better position to minimize them and, thereby, improve the human condition." While the current work on civil war is indeed impressive, one should note that the vast majority of the variables identified as having a causal impact on civil war, such as poverty, population, and regime type, are either difficult to change in the short term or are factors current policy makers already seek to change. Thus, this paper heeds the advice Moore gave over 10 years ago by examining a factor that can be manipulated: education. Further, it seems that conflict scholars have begun to reach the limits of what can be discovered from quantitative studies of civil conflict that rely primarily on aggregate economic variables. As Sambanis (2004a) argues, it is time to move beyond these studies to find more specific causal mechanisms associated with civil war.

This study seeks to tap into more nuanced measures than those used by past scholars in order to draw a specific link between the microlevel factors causing people to join an insurgency and macrolevel data able to draw out this phenomenon in a systematic manner. Thus far, scholars have presented work focused on normative or theoretical reasons as to why education should affect civil war (Sirleaf 1991:32-36; Mayssam 1995:70-74; Elbadawi and Sambanis 2000:247, 258-259; Belloni 2001:171, 177; Aoki et al. 2002:237; Murshed 2002:392; Addison and Murshed 2003:165, 173; Awofeso et al. 2003:313, 324; Amamio 2004; Knight and Ozerdem 2004:503-512; Keen 2005:77). Similarly, scholars have provided some empirical evidence suggesting that education has an impact on civil war (Collier 2000:7, 16; Perez 2003:644; Collier and Hoeffler 2004:569, 588, 594; Collier, Hoeffler, and Soderbom 2004:266, 272; Murdoch and Sandler 2004:139-140; Ross 2004). However, the former literature fails to provide systematic empirical evidence regarding the effect of education on civil war, while the latter literature fails to examine the impact of education beyond the rebel recruitment argument. The following analysis is an attempt to bridge and extend these two literatures.

\section{Government Signals, Grievances, and Education}

Investment in domestic institutions is one way in which the government can signal that it cares about the population. This can be done in a variety of ways, such as increased spending for water sanitation, securing basic health needs, or providing a strong system of education. While each of these provides an interesting area for research, this work focuses primarily on government investment in education as a means to reduce grievances and promote domestic stability. One method by which educational investment can reduce grievances is its ability to create economic development and social equality, each of which lowers grievances that lead to civil war. A plethora of research supports the claim that education leads to economic growth (Adeola 1996; Granato et al. 1996). In addition to creating economic growth, recent studies have found that education leads to more equitable economic growth than other sources of income, such as natural resource development (Saint-Paul and Verdier 1992; Hojman 1996; Londono 1996; Reynolds 1996; Birdsall 1998). The obvious corollary to the argument is that inequalities in education should be reflected by inequalities in society, which has been substantiated by a wide body of research from political scientists, educational specialists, and economists (Sen 1973; Reynolds 1996; Inter-American Development Bank 1999; López-Acevedo 2001).

\footnotetext{
${ }^{1}$ Throughout this paper, "education" refers to institutionalized education as provided by the state. This should not be confused with other forms of individualized learning, such as home schooling.
} 
Ferranti et al. (2004:177) best summarize these arguments, "Education lies at the center of the perpetuation of inequality, both reflecting and influencing unequal economic conditions, power, and social status." Drawing on this work, we should expect a poorly funded system of education to generate poverty and inequality, each of which has been found to increase the likelihood of civil war (Mohammed 1999; Hegre et al. 2001; Sambanis 2001; Elbadawi and Sambanis 2002; Collier et al. 2003; Fearon and Laitin 2003; Collier and Hoeffler 2004).

While the process explained above requires using income inequality as a part of a causal link between education and civil war, a second grievance explanation provides a more direct theory of this relationship. A World Bank report explains, "Education is one of the most powerful instruments societies have for reducing deprivation and vulnerability: it helps lift earnings potential, expands labor mobility, promotes the health of parents and children, reduces fertility and child mortality, and affords the disadvantaged a voice in society and the political system" (Aoki et al. 2002:4). The report goes on to explain how investment in education is a means by which a government can make a direct and lasting impact on the lives of its people, which can lower grievances in a society. Specifically, parents can see schools being built and are likely to be more satisfied if their kids are attending a well-maintained school. Young adults know whether or not there is access to adequate secondary schools and opportunities for post-high school education. Poor or unequal educational investment signals to the population that a government cares little for the people, which is a grievance that could foment rebellion. Recent studies of regimes in Latin America found that nondemocratic regimes, where we find the vast majority of civil wars, spend less on education than more liberal regimes (Brown and Hunter 2004). Thus, we have at least preliminary evidence indicating that the lack of social investment in repressive regimes generates grievances, which may ultimately lead to rebellion. ${ }^{2}$

The case study literature is rich with more specific arguments directly linking education, grievances, and civil war. For example, the failure of the Sudanese government to provide educational resources adequately for the southern region has been cited as a major grievance leading to a 22-year-long civil war (Glickman 2000; Deng 2001; Breidlid 2005). Inadequate investment in primary education in the non-Arab southern region, including less than $14 \%$ of the primary schools for roughly $45 \%$ of the population, left the vast majority of children in the region uneducated, leaving the country ripe for rebellion (Countrystudies. US. 2005). In a more detailed analysis, Peters and Richards (1998:187) provide a direct link between education and civil war using a series of interviews with former fighters in the Sierra Leone civil war, focusing on the subjects' motivations for joining the combat groups. Summarizing these interviews, the authors explain that "time and again interviewees return to the theme of educational aspirations [as causes for joining the fighting]." Similarly, Richards (2003) places the failure of the government to provide an adequate education at the center of rebel decisions to go to war in Sierra Leone. At the primary level, he explains, the problem is structural: children cannot obtain an education because the teachers have not been paid or the school has collapsed. The root of this structural collapse, of course, is linked back to the government, becoming a rallying point for rebel entrepreneurs and a causus belli for the uneducated and unemployed. Importantly, these authors do not simply imply that poor systems of education work through some other mechanism to lead to rebellion; rather, the failure of the government to provide for an adequate education system is so severe that it, in itself, is the root of rebellion. Richards (2003:4) makes this abundantly clear in his critique of Collier's (2000) work: "[Collier] finds

\footnotetext{
${ }^{2}$ This argument is made in a similar fashion regarding people's access to resources. For instance, Critchley and Terriff (1993) examine the limited availability of water resources, which can place stress on a society, engendering instability, and ultimately making a state more susceptible to internal conflict.
} 
low education a correlate of civil war, but excludes lack of access to education from the list of grievances. This makes nonsense of the evidence. Those who fight the war in Sierra Leone consider lack of education their grievance!"

Drawing on the two arguments above, we can see how education has both a direct and indirect effect on the grievances that may foment rebellion. This theory, therefore, speaks to the more general work identifying the structural causes of civil war, while also answering Sambanis' (2004a:259) call for researchers to examine "the causal pathways that link individual or group behavior with the outbreak of civil war." Two measures in particular would provide an excellent test of how education might produce grievances that could lead to civil war. The first, aggregate government spending in education, is a clear indicator of how much the government supports education compared with other potential areas of funding. This leads to the first hypothesis:

Hypothesis 1: Increased government investment in education decreases the probability of civil war onset.

While educational investment is a reasonable test for how well the government is responding to the needs of the people, it is possible that aggregate education investment data hide a system that may actually foment rebellion. Several authors have argued that educational expenditures are often distributed unequally to the university level, which disproportionately helps the wealthy, especially in poor societies. Increased education expenditures, therefore, could actually foment rebellion because they perpetuate (or intensify) existing social and economic inequality. For this reason, scholars such as Brown and Hunter (2004) use primary educational investment as a percent of total educational investment as a measure of equitably distributed education funds. Owing to incompleteness of data, a similar indicator, primary enrollment, is used for this analysis. Primary enrollment rates are a reasonable proxy for equitable educational investment for two main reasons. First, primary enrollment is an outcome variable that captures how educational investment from the government actually reaches those who need it. Spending measures, on the other hand, may show false responsiveness as funds get trapped in bureaucratic inefficiency, misallocation to the wealthy, or corruption. ${ }^{3}$ Second, according to past international agreements such as the UN Convention on the Rights of the Child (1989), a high level of primary enrollment is an expectation for every country. Therefore, we can reasonably expect all responsive governments to provide universal access to primary education. This leads to the second hypothesis:

Hypothesis 2: Increased primary enrollment rates decrease the probability of civil war onset.

\section{Education and Stability}

The creation of social and political stability provides a second causal mechanism by which education can decrease the likelihood of civil war onset. Early political theorists, such as Montesquieu, Locke, Rousseau, Mill, and Aristotle, argued that education empowers individuals and communities for effective citizenship and promotes a culture of peace (Sargent 1996). More recently, scholars have argued that education promotes social cohesion, which provides social and economic stability. Amamio (2004:4) best summarizes this argument, "governments must shift their central priorities from accumulating political and military power toward building a stronger educational infrastructure for peace. Security and stability are

\footnotetext{
${ }^{3}$ For example, scholars such as Paul and Wolff (1996), Reynolds (1996:42), Birdsall, London and O'Connell (1998), Hunter and Brown (2000), and Brown and Hunter (2004) have argued that education funding in Latin America has gone disproportionately to the university level, which primarily benefits the wealthy in society.
} 
all dependent upon a sound education." Heyneman (2003:29-30) provides a strong theoretical rationale for this notion, explaining four ways in which education leads to social cohesion. First, schools teach people the interpersonal, political, social, and legal principles that underlie good citizenship, the obligations of political leaders, the behavior expected of citizens, and the consequences for not adhering to these behaviors. Second, the classroom brings together people of different origins and teaches them how to work together peacefully. Third, schools seek to provide equality of opportunity for students, giving them each a chance for success in life. Finally, school systems combine the interests and objectives of a wide range of groups while trying to establish a common underpinning for citizenship.

Political scientists have also looked at education as a means of providing stability. Lipset (1959) argues that education broadens one's outlook, increases tolerance for other members of society, restrains extremist activity and doctrines, and increases a person's ability to pursue their interests using the political process. Brady, Verba, and Schlozman (1995) and Almond et al. (2004:67) add that schools are one of several agents of socialization that provide people the means by which to pursue their needs in a peaceful manner. They argue that education provides civic skills to the people, ultimately leading to increased political participation and social stability.

The ability of education to create social cohesion has two consequences for the risk of civil war. First, the interpersonal skills students learned in the classroom should be reflected in society, which should make people more apt to seek peaceful resolutions to problems. Second, an educated population is better able to understand poverty, economic development, and the role of government in society. For example, Woolcock, Easterly and Ritzen (2000) note that the social cohesion produced by education permits governments to make progressive changes, such as those promulgated by the World Bank and IMF, that may hurt in the short term but will ultimately help in the long run. Therefore, we should expect education to have a negative effect on the incidence of civil war, even in times of poverty and turmoil.

In addition to uniting the country through classroom instruction, education can promote stability by helping a government defend itself and by increasing the opportunity costs of would-be rebel organizations. By re-examining the argument that education leads to wealth, we can also infer that education leads to more tax revenue for the government, giving it resources to defend itself against rebel attacks. Collier (2000) explains that governments in the developing world in the early 1980 s were raising only around $6 \%$ of national income from taxation due to poor economies, which dramatically decreased their ability to defend themselves from rebel organizations. In addition to providing resources for the government, a strong education system effectively decreases the potential power of rebel organizations because it decreases the incentive that young men have to challenge the government. Collier (2000) provides a partial test of this argument, finding that conflict is concentrated in countries with poor systems of education.

We could potentially draw on many educational indicators to evaluate the potential stability provided by education. Collier and Hoeffler (2004) have performed some preliminary work that introduces education into analyses of civil war onset. They use secondary male enrollment in their "opportunity" model based on the argument that low enrollment lowers the costs of rebel recruitment due to the ample supply of idle young males with little hope for a bright future. To ensure the consistency of these results with past civil war research, Collier and Hoeffler's secondary male enrollment variable is tested with the following hypothesis:

Hypothesis 3: As rates of secondary male enrollment increase, the probability of civil war onset decreases.

Building on Collier and Hoeffler's work, three measures are used to further the analysis of the effect of education as a stability measure, including (1) levels of 
overall secondary enrollment, (2) postsecondary enrollment, and (3) adult literacy rates. The percentage of eligible students attending secondary and postsecondary schools tells us whether the government is currently providing a place to create social cohesion among those most likely to rebel against the government. If a high percentage of teenagers are attending classes, we can expect that in most cases, the government is using at least a portion of the class time to promote the state, much like government classes in U.S. high schools. Similarly, we can generally find the future leaders in a state being trained in universities, which are likely geared at least indirectly toward teaching students how to work together to solve problems. Literacy rates give us a similar understanding of education levels in the adult population. We can reasonably assume that people in a population became literate through classroom instruction, which means that they were likely also trained to work together peacefully and to respect the state. Additionally, an educated person has more economic opportunities, which will make him or her less likely to risk death or prison by joining rebel organizations. Theoretically, we should expect all three indicators to have a negative effect on the probability of civil war due to the increased stability generated by each education variable. This leads to the final hypothesis.

Hypothesis 4: As indicators of adult education increase, the probability of civil war onset decreases.

Before proceeding to test these hypotheses, two counterarguments to this theory should be addressed. First, the notion that systems of higher education promote stability is likely viewed skeptically by those working on a university campus, which is often the center of civil disobedience in a society. It is quite possible that high levels of education actually lead to a higher probability of civil distress, as students lead protests for political change. This speaks to an important distinction between civil conflict and civil war. ${ }^{4}$ Civil conflict may include riots, coups or other forms of low-level protests. Civil wars, as broadly defined in the literature, require a high threshold of deaths and a direct attempt to overthrow the government violently or secede from the state (Sambanis 2004b). The argument above and the tests that follow speak only to the latter sort, civil wars, where violence is high and the insurgents risk death for the cause. While students often are at the forefront of antigovernment activism, economic models of civil war suggest that those with the most to lose (e.g., educated people) should be the least likely to risk death by joining insurgencies (Grossman 1991, 1999). The situation in Sierra Leone provides an excellent example of this distinction. As the single-party-dominated All People's Congress (APC) waned in power in the 1980s, university students began to protest against single-party rule. A strongly repressive response from the government caused the students to back away, being replaced by a violent movement from the unemployed and uneducated youth from urban Freetown (Weinstein 2005). Thus, while high levels of education may lead to low-level protest activity, we should expect the opposite effect for all-out rebellions.

A second theoretical critique is that education can be used as a means of indoctrination, fueling chauvinism, militarism, and violent religious extremism, which may increase the probability of civil war onset. Examples include Hezbollah's antiSemitic teachings in Palestine or anti-Western and antigovernment curriculum in Pakistani madrassas (Stern 2000; Dalrymple 2005). While these cases indeed highlight potential errors in equating the quantity of education with its quality, they do not necessarily limit the argument of this paper. This is because extremist education is often the result of the failure of the government to provide an adequate edu-

\footnotetext{
${ }^{4}$ See Eckstein (1964) for an excellent discussion of the distinction between civil wars and other forms of domestic violence.
} 
cation to the population, creating a void to be filled by extremist elements in society. For example, Dalrymple (2005) notes that less than 2\% of Pakistan's gross domestic product (GDP) is spent on government schools, resulting in deplorable conditions for the country's educational system. ${ }^{5}$ Therefore, the success of nongovernmental madrassas in Pakistan, and the resulting antigovernment violence coming from them, is a direct result of the failure of the government to fund its system of education adequately. This, in fact, supports the argument of this paper.

\section{Research Design, Data, Measurement, and Model}

The purpose of this paper is to examine whether education adds any additional leverage to our explanation of the onset of civil war. It makes sense, therefore, to add these variables to an existing model of civil war onset in order to test the education hypotheses. Fearon and Laitin's (2003) examination of civil war onset provides the most comprehensive large- $\mathrm{N}$ analysis of the determinants of civil war to date. Their analysis tests most major hypotheses from the literature, often using several proxies for each hypothesis and several variations of the dependent variable. The hypotheses developed in this paper are tested by combining the education variables (described below) with Fearon and Laitin's cases, dependent variable, and control variables. The data set is time-series cross-sectional including 160 countries from 1980 through 1999. Fearon and Laitin's (2003) data span from around 1945 to 1999 . Owing to limitations in the education data, however, this data set is smaller temporally (1980-1999) and includes many more missing data points due to incomplete education and literacy data. The standard method of dealing with missing data is to use listwise deletion, which simply omits the observation from the analysis. However, King et al. (2001) explain that this method can result in both inefficient and biased parameter estimates. Further, listwise deletion in this data set results in the loss of an extraordinary amount of information because the observation is usually missing just one or two variables in the entire model. In order to avoid the potential problems involved in running the statistical analysis with missing data, the Amelia data imputation program created by Honaker et al. (2001) is used to generate values for the missing data. Amelia generates data for missing cells based on the observed data in the same row with the assumption that the missing values are missing at random (MAR). ${ }^{6}$ The authors explain that it is necessary to include as many variables in the imputation process as possible to make the MAR assumption hold as firmly as possible. ${ }^{7}$ Once a data set is complete with as many relevant variables as possible, Amelia then imputes $m$ data sets with estimations of missing values. ${ }^{8}$ Regressions are then run across the $m$ data sets, giving combined coefficients and standard errors. This procedure is nearly identical to that run by Stasavage (2005:348-9) for his analysis of education spending in Africa.

\section{Dependent Variable: Civil War Onset}

The dependent variable, civil war onset, is a dichotomous variable from Fearon and Laitin (2003:76), who define "civil war" based on three criteria: (1) the war involved fighting between agents of (or claimants to) a state and organized, nonstate groups who sought either to take control of a government, to take power in a region, or to

\footnotetext{
${ }^{5}$ Specifically, $15 \%$ of the schools lack a proper building; $40 \%$ are without water; and $71 \%$ without electricity (Dalrymple, 2005).

${ }^{6}$ MAR refers to cases with incomplete data where the missingness is traceable or predicable from the other variables in the data set (King et al. 2001).

${ }^{7}$ Descriptive statistics for the data before and after Amelia are available on the author's website. All other analyses referred to in the text, including those not presented in the tables, are also available on the author's website.

${ }^{8}$ The default setting for $m$ is 5 , which is used in this analysis. The analyses were also run with $m=10$ and 20 . No important differences in the means, deviations, or empirical results were observed.
} 
use violence to change government policies; (2) the conflict killed at least 1,000 over its course, with a yearly average of at least 100; and (3) at least 100 were killed on both sides (including civilians attacked by rebels). Following this definition, civil war onset is a dichotomous variable coded one (1) for each country-year in which a civil war began and zero (0) otherwise. The onset variable includes 49 cases of civil war onset from 1980 to $1999 .^{9}$

\section{Independent (Education) Variables}

The first independent variable, investment in education, is the amount of total government expenditures allocated toward education as a percentage of that state's GNP. This includes expenditures on public education plus subsidies to private education at the primary, secondary, and postsecondary levels. The education expenditures data come from the UNESCO Institute for Statistics (2004). Along with expenditures, we should expect primary enrollment rates to work as a proxy for grievances in a society. Given the argument that aggregate expenditures potentially hide unequal investment in education, which might have the effect of fomenting rebellion, the primary enrollment indicator is perhaps the best proxy for the grievance hypotheses. The next set of independent variables includes enrollment levels for secondary enrollment, postsecondary enrollment, and adult literacy rates. Secondary enrollment is also split into male-only secondary enrollment, based on Collier and Hoeffler's (2004) argument that low levels of male enrollment lower the costs of rebel recruitment. The enrollment data are a ratio of total enrollment, regardless of age, to the population of the age group that officially corresponds to the indicated level of education (primary, secondary, or postsecondary). Estimates are taken from the World Bank's WDI database (2004), which are based on UNESCO's classification of education levels (WDI methodology 2004). Finally, adult literacy rates are the proportion of adults aged 15 and above who can, with understanding, read and write a short, simple statement on their everyday life (WDI methodology 2004). Literacy data come from UNESCO's Institute for Statistics (2004). We should expect these proxies of an educated society to have a negative effect on the onset of civil war because they promote stability in society. ${ }^{10}$ In fact, according to the theory, any one of these variables should be a reasonable proxy to test the final hypothesis. All three variables are included in the model, however, in order to better understand exactly where funding should be concentrated in order to prevent future civil wars.

\section{Noneducation/Control Variables}

One of the most impressive contributions of Fearon and Laitin's (2003) model is the breadth of their statistical tests for each major argument presented in the literature to date. Fearon and Laitin (2003) include a handful of control variables in their models. Owing to space constraints, the following paragraph will simply introduce the variables. The reader is encouraged to review the original research for a more thorough explanation. The first variable, prior war, is a dummy variable indicating whether a country had a distinct civil war ongoing in the previous year. It is used to control for possible temporal dependence between observations. The second, per capita income, tests the argument that there exist fewer grievances in a society with higher levels of income. The next three measures, population, mountainous terrain,

\footnotetext{
${ }^{9}$ Results were also tested using similar definitions of civil war onset from Hegre et al. (2001), Sambanis (2001), the PRIO data set (Gleditsch et al. 2002), and Collier and Hoeffler (2004). No important differences in the results were observed.

${ }^{10}$ The stability hypothesis was also tested using variables for average years of higher schooling, higher schooling in the adult population, and these measures for the male population only, from the Barro and Lee (1996) education data. Results are similar to those presented in this article.
} 
and noncontiguous state, are included as proxies for state strength. The sixth variable, oil exporter, is a dummy variable for all country-years in which fuel exports exceeded one-third of export revenues. It tests the argument that oil producers tend to have weak state apparatuses. The next two variables, new state and instability, capture possible weakness and disorganization in states that have recently become independent or have undergone major transitions. The ninth and tenth variables, ethnic fractionalization and religious fractionalization, capture the notion that civil wars are more frequent in heavily heterogeneous societies. The final two variables, anocracy and democracy, test whether regime type helps explain the probability of civil war onset.

\section{Analysis of Results}

Tables 1 and 2 present the empirical tests of the hypotheses. The first model in Table 1 presents the original baseline model from Fearon and Laitin (2003:84; Table 1, Model 3). The second model shows these results replicated for the 1980-1999

TABLE 1. Logit Analyses of Determinants of Civil War Onset: Grievance Variables

\begin{tabular}{|c|c|c|c|c|c|c|c|}
\hline & Model 1 & Model 2 & Model 3 & Model 4 & Model 5 & Model 6 & $\% \Delta$ \\
\hline Primary enrollment & & & & $\begin{array}{c}-0.029 * * \\
(0.009)\end{array}$ & & $\begin{array}{c}-0.027 * * \\
(0.009)\end{array}$ & -73 \\
\hline $\begin{array}{l}\text { Education } \\
\text { expenditure/GNP }\end{array}$ & & & & & $\begin{array}{r}-0.184^{\dagger} \\
(0.103)\end{array}$ & $\begin{array}{r}-0.136 \\
(0.101)\end{array}$ & -54 \\
\hline Prior war & $\begin{array}{c}-0.916^{* *} \\
(0.312)\end{array}$ & $\begin{array}{r}-1.08^{* * *} \\
(0.443)\end{array}$ & $\begin{array}{r}-1.24 * * \\
(0.450)\end{array}$ & $\begin{array}{r}-1.35^{* * *} \\
(0.435)\end{array}$ & $\begin{array}{r}-1.33^{* * *} \\
(0.442)\end{array}$ & $\begin{array}{c}-1.43^{* * * *} \\
(0.438)\end{array}$ & -66 \\
\hline Income/capita & $\begin{array}{c}-0.318^{* * * *} \\
(0.071)\end{array}$ & $\begin{array}{c}-0.512 * * * * \\
(0.139)\end{array}$ & $\begin{array}{c}-0.326^{* * *} \\
(0.103)\end{array}$ & $\begin{array}{r}-0.226^{*} \\
(0.098)\end{array}$ & $\begin{array}{c}-0.312^{* * * *} \\
(0.090)\end{array}$ & $\begin{array}{r}-0.210^{*} \\
(0.101)\end{array}$ & -81 \\
\hline Population $^{\ddagger}$ & $\begin{array}{l}0.272^{* * * *} \\
(0.074)\end{array}$ & $\begin{array}{r}0.257 * \\
(0.112)\end{array}$ & $\begin{array}{c}0.227 * \\
(0.113)\end{array}$ & $\begin{array}{c}0.253^{*} \\
(0.119)\end{array}$ & $\begin{array}{r}0.194^{\dagger} \\
(0.114)\end{array}$ & $\begin{array}{r}0.226^{\dagger} \\
(0.121)\end{array}$ & +76 \\
\hline Percent mountainous ${ }^{\ddagger}$ & $\begin{array}{c}0.199^{*} \\
(0.085)\end{array}$ & $\begin{array}{c}0.160 \\
(0.118)\end{array}$ & $\begin{array}{c}0.155 \\
(0.115)\end{array}$ & $\begin{array}{c}0.206^{\dagger} \\
(0.12)\end{array}$ & $\begin{array}{c}0.153 \\
(0.114)\end{array}$ & $\begin{array}{c}0.221^{\dagger} \\
(0.121)\end{array}$ & +72 \\
\hline Noncontiguous state & $\begin{array}{c}0.426 \\
(0.272)\end{array}$ & $\begin{array}{r}0.890 * \\
(0.497)\end{array}$ & $\begin{array}{r}0.956^{*} \\
(0.468)\end{array}$ & $\begin{array}{c}1.19^{*} \\
(0.475)\end{array}$ & $\begin{array}{l}1.03^{*} \\
(0.471)\end{array}$ & $\begin{array}{r}1.24^{* * *} \\
(0.480)\end{array}$ & +212 \\
\hline Oil exporter & $\begin{array}{l}0.751^{* * *} \\
(0.278)\end{array}$ & $\begin{array}{c}0.230 \\
(0.439)\end{array}$ & $\begin{array}{c}0.200 \\
(0.417)\end{array}$ & $\begin{array}{c}0.373 \\
(0.417)\end{array}$ & $\begin{array}{c}0.207 \\
(0.410)\end{array}$ & $\begin{array}{c}0.372 \\
(0.419)\end{array}$ & - \\
\hline New state & $\begin{array}{l}1.658^{* * * *} \\
(0.342)\end{array}$ & $\begin{array}{l}2.16^{* * * *} \\
(0.664)\end{array}$ & $\begin{array}{l}2.01^{* * * *} \\
(0.567)\end{array}$ & $\begin{array}{l}2.06^{* * * *} \\
(0.577)\end{array}$ & $\begin{array}{l}2.18^{* * * *} \\
(0.579)\end{array}$ & $\begin{array}{l}2.20^{* * * *} \\
(0.595)\end{array}$ & +692 \\
\hline Instability & $\begin{array}{c}0.513^{*} \\
(0.242)\end{array}$ & $\begin{array}{c}0.252 \\
(0.380)\end{array}$ & $\begin{array}{c}0.232 \\
(0.374)\end{array}$ & $\begin{array}{c}0.029 \\
(0.393)\end{array}$ & $\begin{array}{c}0.175 \\
(0.369)\end{array}$ & $\begin{array}{c}0.012 \\
(0.392)\end{array}$ & - \\
\hline Anocracy & $\begin{array}{r}0.521^{*} \\
(0.237)\end{array}$ & $\begin{array}{r}1.07 * * \\
(0.399)\end{array}$ & $\begin{array}{r}1.02^{* * *} \\
(0.383)\end{array}$ & $\begin{array}{r}1.03 * * \\
(0.344)\end{array}$ & $\begin{array}{l}1.09 * * * * \\
(0.335)\end{array}$ & $\begin{array}{r}1.08^{* * *} \\
(0.346)\end{array}$ & +168 \\
\hline Ethnic fract. & $\begin{array}{c}0.164 \\
(0.368)\end{array}$ & $\begin{array}{c}0.284 \\
(0.607)\end{array}$ & $\begin{array}{c}0.600 \\
(0.603)\end{array}$ & & & & - \\
\hline Religious fract. & $\begin{array}{c}0.326 \\
(0.506)\end{array}$ & $\begin{array}{r}-0.123 \\
(0.797)\end{array}$ & $\begin{array}{r}-0.031 \\
(0.758)\end{array}$ & & & & - \\
\hline Democracy & $\begin{array}{c}0.127 \\
(0.304)\end{array}$ & $\begin{array}{c}0.257 \\
(0.472)\end{array}$ & $\begin{array}{c}0.118 \\
(0.477)\end{array}$ & & & & - \\
\hline Constant & $\begin{array}{c}-7.019^{* * * *} \\
(0.751)\end{array}$ & $\begin{array}{c}-6.27 * * * * \\
(1.16)\end{array}$ & $\begin{array}{c}-6.45^{* * * *} \\
(1.13)\end{array}$ & $\begin{array}{c}-4.41^{* * * *} \\
(1.20)\end{array}$ & $\begin{array}{c}-5.18^{* * * * *} \\
(1.16)\end{array}$ & $\begin{array}{c}-3.86^{* *} \\
(1.24)\end{array}$ & \\
\hline Onset events & 111 & 49 & 49 & 49 & 49 & 49 & \\
\hline Observations & 6,327 & 2,744 & 2,904 & 2,904 & 2,904 & 2,904 & \\
\hline
\end{tabular}

Standard errors are in parentheses. Estimations performed using Stata 8.0.

${ }^{\dagger} p<.10, * p<.05, * * p<.01, * * * p<.001$ (two tailed). $\% \Delta$ refers to the change in the probability of civil conflict when moving the row variable from one standard deviation (1 SD) below the mean to $1 \mathrm{SD}$ above the mean while holding all other variables constant. Values are for Model 6 except for educational expenditures (Model 5).

${ }^{\ddagger}$ Values are logged. 
TABLE 2. Logit Analyses of Determinants of Civil War Onset: Stability Variables

\begin{tabular}{|c|c|c|c|c|c|c|c|c|}
\hline & Model 1 & $\% \Delta$ & Model 2 & $\% \Delta$ & Model 3 & $\% \Delta$ & Model 4 & $\% \Delta$ \\
\hline $\begin{array}{l}\text { Secondary } \\
\text { enrollment }\end{array}$ & $\begin{array}{r}-0.014^{\dagger} \\
(0.007)\end{array}$ & -63 & & & & & & \\
\hline $\begin{array}{c}\text { Secondary male } \\
\text { enrollment }\end{array}$ & & & $\begin{array}{c}-0.024^{* * *} \\
(0.008)\end{array}$ & -68 & & & & \\
\hline $\begin{array}{c}\text { Postsecondary } \\
\text { enrollment }\end{array}$ & & & & & $\begin{array}{c}0.014 \\
(0.014)\end{array}$ & - & & \\
\hline Literacy rate & & & & & & & $\begin{array}{r}-0.015^{\dagger} \\
(0.008)\end{array}$ & -43 \\
\hline Prior war & $\begin{array}{r}-1.20 * * \\
(0.432)\end{array}$ & -70 & $\begin{array}{r}-1.26^{* * *} \\
(0.434)\end{array}$ & -53 & $\begin{array}{r}-1.21 * * \\
(0.445)\end{array}$ & -63 & $\begin{array}{r}-1.19 * * \\
(0.433)\end{array}$ & -56 \\
\hline Income/capita & $\begin{array}{r}-0.246^{*} \\
(0.108)\end{array}$ & -100 & $\begin{array}{r}-0.182^{\dagger} \\
(0.106)\end{array}$ & -71 & $\begin{array}{c}-0.388^{* * *} \\
(0.112)\end{array}$ & -96 & $\begin{array}{c}-0.278^{* * *} \\
(0.102)\end{array}$ & -88 \\
\hline Population $^{\ddagger}$ & $\begin{array}{r}0.252^{*} \\
(0.113)\end{array}$ & +109 & $\begin{array}{r}0.275^{*} \\
(0.115)\end{array}$ & +80 & $\begin{array}{l}0.222^{*} \\
(0.113)\end{array}$ & +79 & $\begin{array}{c}0.243^{*} \\
(0.113)\end{array}$ & +82 \\
\hline Percent mountainous ${ }^{\ddagger}$ & $\begin{array}{c}0.150 \\
(0.113)\end{array}$ & - & $\begin{array}{c}0.149 \\
(0.114)\end{array}$ & - & $\begin{array}{c}0.126 \\
(0.114)\end{array}$ & - & $\begin{array}{c}0.175 \\
(0.114)\end{array}$ & - \\
\hline Noncontiguous state & $\begin{array}{c}1.02 * \\
(0.464)\end{array}$ & +177 & $\begin{array}{c}1.18^{*} \\
(0.467)\end{array}$ & +166 & $\begin{array}{r}.938^{*} \\
(0.459)\end{array}$ & +140 & $\begin{array}{r}.970 * \\
(0.464)\end{array}$ & +139 \\
\hline Oil exporter & $\begin{array}{c}0.242 \\
(0.410)\end{array}$ & - & $\begin{array}{c}0.315 \\
(0.414)\end{array}$ & - & $\begin{array}{c}0.187 \\
(0.408)\end{array}$ & - & $\begin{array}{c}0.193 \\
(0.409)\end{array}$ & - \\
\hline New state & $\begin{array}{l}2.49 * * * * \\
(0.622)\end{array}$ & +111 & $\begin{array}{l}2.78^{* * * *} \\
(0.625)\end{array}$ & +111 & $\begin{array}{l}1.85^{* * * * *} \\
(0.581)\end{array}$ & $\begin{array}{c}+484 \\
4\end{array}$ & $\begin{array}{l}2.28^{* * * *} \\
(0.591)\end{array}$ & +741 \\
\hline Instability & $\begin{array}{c}0.174 \\
(0.373)\end{array}$ & - & $\begin{array}{c}0.130 \\
(0.378)\end{array}$ & - & $\begin{array}{c}0.232 \\
(0.367)\end{array}$ & - & $\begin{array}{c}0.200 \\
(0.369)\end{array}$ & - \\
\hline Anocracy & $\begin{array}{r}1.07 * * * \\
(0.337)\end{array}$ & +192 & $\begin{array}{l}1.12^{* * * * *} \\
(0.341)\end{array}$ & +152 & $\begin{array}{c}.986^{* * *} \\
(0.334)\end{array}$ & +152 & $\begin{array}{r}1.04^{* * *} \\
(0.332)\end{array}$ & +155 \\
\hline Constant & $\begin{array}{c}-6.02 * * * * \\
(1.07)\end{array}$ & - & $\begin{array}{c}-5.98 * * * * \\
(1.08)\end{array}$ & & $\begin{array}{c}-6.02^{* * * * *} \\
(1.07)\end{array}$ & & $\begin{array}{c}-5.43^{* * * *} \\
(1.12)\end{array}$ & \\
\hline Onset events & 49 & & 49 & & 49 & & 49 & \\
\hline Observations & 2,904 & & 2,904 & & 2,904 & & 2,904 & \\
\hline
\end{tabular}

Standard errors are in parentheses. Estimations performed using Stata 8.0.

${ }^{\dagger} p<.10, * p<.05, * * p<.01, * * * p<.001$ (two tailed). $\% \Delta$ refers to the change in the probability of civil conflict when moving the row variable from one standard deviation (1 SD) below the mean to 1 SD above the mean while holding all other variables constant.

${ }^{\ddagger}$ Values are logged.

period. The third model shows the same data after Amelia iterations were run to fill in missing values. These data provide two notable pieces of information. First, by comparing the first two models, we see that there is little important information lost when the analysis is limited to the smaller temporal period. The few differences that exist are addressed later. Second, by comparing the second and third models, we see that the results before and after Amelia imputations are nearly identical, which provides sound evidence that the imputations will not add any particular bias to the results. Having verified an acceptable baseline model, subsequent analyses drop the variables for ethnic fractionalization, religious fractionalization, and democracy. This is done for three reasons. First, given that they do not add any explanatory power to the model, dropping them provides for a more parsimonious overall model. Second, several authors have noted problems with the fractionalization variables (e.g., Quinn, Hechter, and Wibbels 2003), making it wise to remove them from this and subsequent analyses. Third, the substantive results are identical with or without the variables.

Moving to the tests of the hypotheses, we should expect both educational expenditures and primary enrollment to have a negative effect on the onset of civil 
war if the first two hypotheses (grievance theory) are to be supported. Looking at Table 1 (Models 4-6), we find strong support for the grievance hypotheses. First, the educational expenditures variable (Model 5) is negative and significant $(p=.081)$, indicating that an increase in aggregate educational expenditures leads to a decrease in the probability of civil war onset (Hypothesis 1). This variable drops from significance in the combined model (Model 6), suggesting a minor problem of collinearity with the primary enrollment variable $(r=0.226)$. The coefficient for primary enrollment (Hypothesis 2), on the other hand, is negative and significant both alone (Model 4) and in the combined model (Model 6), which indicates that increased primary enrollment decreases the probability of civil war onset. In fact, an increase in primary enrollment from 1 standard deviation $(S D)$ below the mean to $1 S D$ above results in a $73 \%$ decrease in the predicted probability of civil war onset. Likewise, increased levels of educational expenditures lead to a $54 \%$ decrease in the probability of civil war when moved from $1 S D$ below the mean to $1 S D$ above.

Moving to the stability variables in Table 2, we see that the variable for secondary male enrollment (Model 2) behaves in a manner expected by previous research (Collier and Hoeffler 2004). That is, higher levels of secondary male enrollment lead to a lower probability of civil war onset. Regarding the final stability variables, the fourth hypothesis predicts a lower probability of civil war onset as secondary enrollment, postsecondary enrollment, and adult literacy rates increase. Unfortunately, these indicators are too highly correlated to include in a combined model $(r>0.80)$. Looking at Table 2, we find moderate to strong support for the fourth hypothesis. The coefficient for literacy (Model 4) is negative and significant $(p=.084)$, which indicates that higher levels of adult literacy lead to a smaller probability of civil war onset. A change from $1 S D$ below the mean to $1 S D$ above results in a $43 \%$ decrease in the predicted probability of the onset of civil war. Similarly, the coefficient for secondary enrollment (Model 1) is negative and significant $(p=.066)$, indicating that increased levels of secondary enrollment lead to a lower probability of civil war onset. Like secondary male enrollment, this variable seems to lend quite a bit of leverage to our explanation of the causes of civil war onset, with a change in $1 S D$ below the mean to $1 S D$ above resulting in a $63 \%$ decrease in the predicted probability of civil war onset. The significance of this variable is interesting, given that it moves the literature beyond a simple rebel recruitment argument. That is, the overall secondary enrollment measure supports recent arguments that general equality has a pacifying effect on internal violence (Caprioli 2005; Melander 2005). This might also reflect the notion that females are increasingly being used as combatants (Kriger 1992; Arthur 1998), making both male and female enrollment important for recruitment. At any rate, the findings suggest support for the argument that a strong system of education, directed at both males and females, has a pacifying effect on civil war.

Finally, the coefficient for postsecondary enrollment (Model 3) fails to attain significance, providing no additional support for the stability argument. The insignificance of this variable may also mean that high levels of university enrollment have a mixed effect, working as a calming influence in some situations and fomenting rebellion in others. Possible indirect effects were tested by interacting postsecondary enrollment with regime type (Polity IV scores) and recent civil war history (dummy variable if the state experienced a civil war in the last 5 years). None of these measures were significant. Another possibility is that the correlation between postsecondary enrollment and income per capita $(r=0.69)$ is too high for both variables to be included in the same model. Indeed, when "income/capita" is dropped from Table 2, Model 3, the coefficient for postsecondary enrollment is negative and significant $(p=.021)$. However, this does not necessarily mean that postsecondary enrollment has a pacifying effect on civil war, given that it is likely working as a proxy for wealth. Thus, the prudent conclusion here is that postsecondary enrollment has no direct pacifying effect on civil war. 


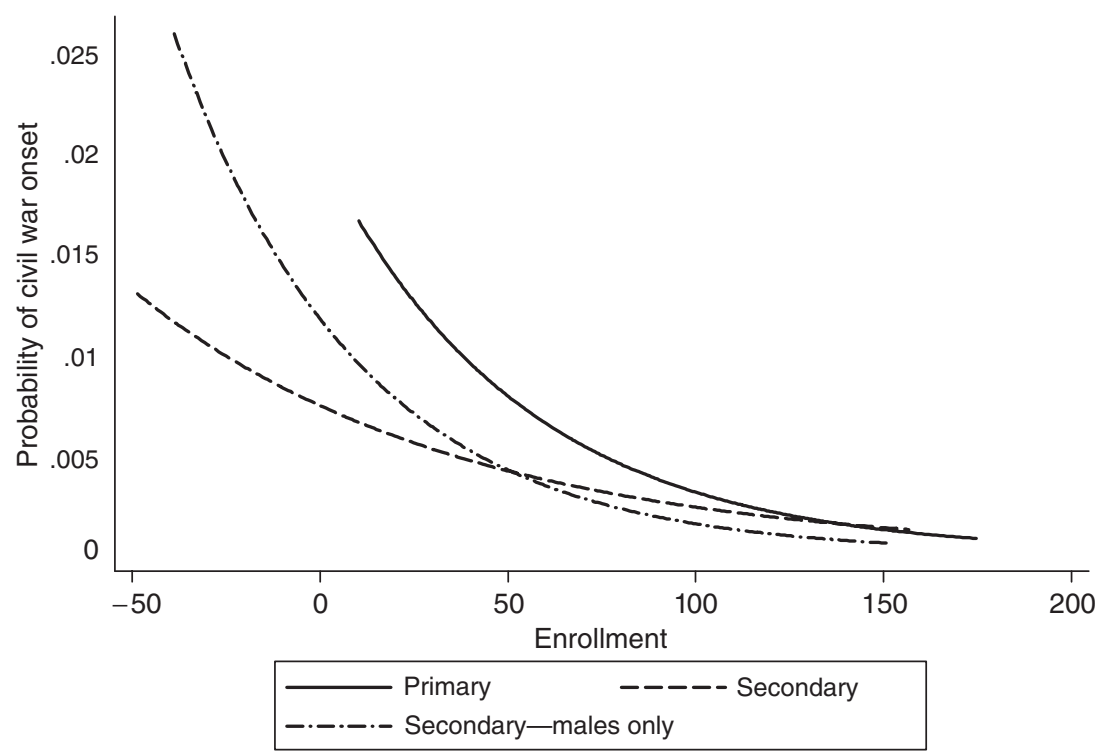

FIG. 1. Marginal Effect of Enrollment Rates on Civil War Onset

A more thorough analysis of the effects of education on the probability of civil war is possible by plotting the marginal effects of each significant education variable while holding all other variables constant. In Figure 1, we see the marginal effects of primary, secondary, and secondary male enrollment on the probability of civil war. This provides several interesting conclusions beyond the coefficients alone. First, each variable slopes downward, indicating that as enrollment levels increase, the probability of civil war decreases. Next, secondary male enrollment has the strongest marginal effect when values are very low, which supports Collier and Hoeffler's (2004) rebel recruitment argument. Third, each variable slopes in a convex shape, indicating that efforts to improve education will have the strongest effects in countries where enrollment levels are extremely low. Once enrollment nears the $100 \%$ mark, increases in the variable will produce very little change in the probability of civil war.

Figure 2 presents the marginal effect plot for education expenditures and literacy rates. Like Figure 1, the effect of these variables has a convex shape and slopes downward, indicating that as each variable increases, the probability of civil war decreases. Unlike enrollment, however, the convex shape for educational expenditures (the solid line) is minimal, indicating that funds directed toward education will have an important pacifying effect on civil war at all levels of funding. The line for adult literacy rates also decreases as values become larger. Unlike the other variables, however, the effect of literacy is quite minimal.

Overall, Figures 1 and 2 provide evidence for specific policy advice to those seeking to prevent future incidences of civil war. First, drawing on the rebel recruitment argument, if enrollment levels are extremely low, priority should be placed on providing education opportunities for young males, who are the most apt to join an insurgency. ${ }^{11}$ Second, drawing on the grievance argument, increased education expenditures will likely have a pacifying effect on internal war, regardless of the current rate of spending on education. Similarly, once young males have an acceptable opportunity for education, investment in primary levels of education will ${ }^{11}$ This advice should be weighed against other issues, such as gender equality, which are beyond the scope of
this article. See Caprioli (2005) and Melander (2005) for excellent work in this area. 


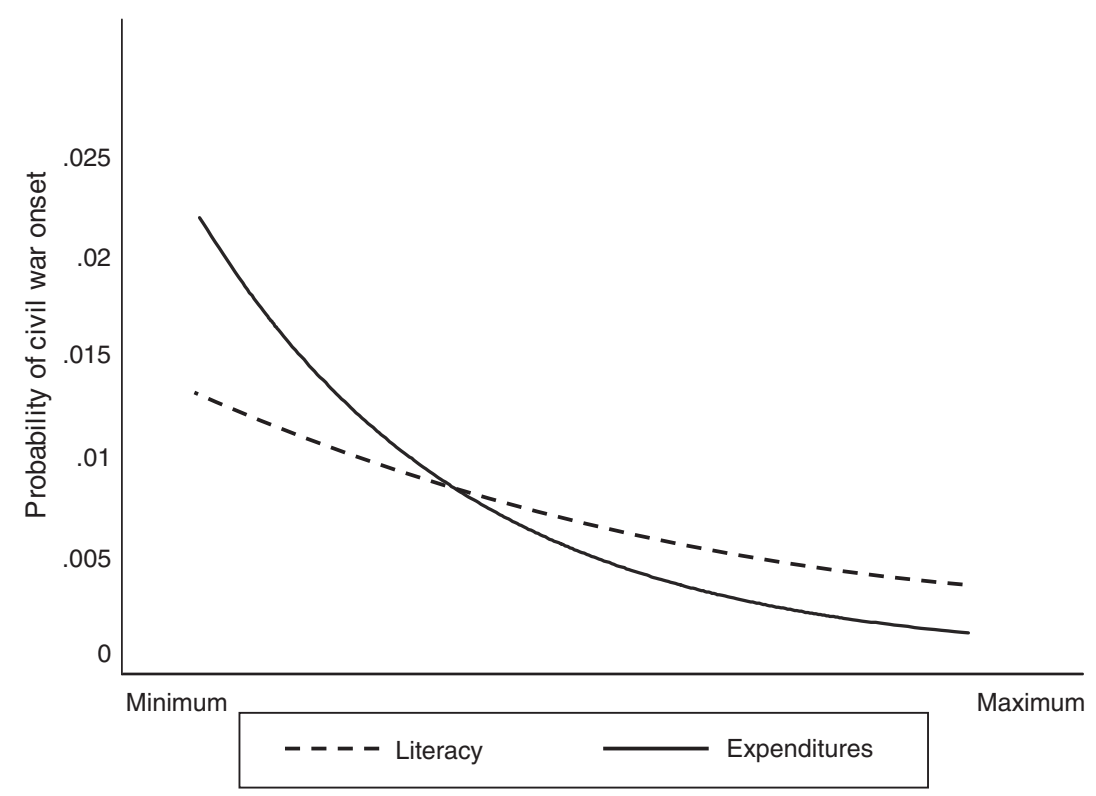

FIG. 2. Marginal Effect of Education Expenditures and Literacy on Civil War Onset Note: The $X$-axis for literacy ranges from 9.8 (minimum) to 145.3 (maximum). The $X$-axis for expenditures ranges from -5.0 (minimum) to 12.9 (maximum).

produce the highest return on the investment if one's goal is to sustain peace. Fourth, drawing on the stability argument, once enrollment levels near $100 \%$ further efforts to increase enrollment will have very little effect on the probability of rebellion. Similarly, increasing levels of adult literacy will have a statistically significant, but substantively minimal, effect on the onset of civil war.

Beyond the education variables, the results shown above provide some interesting conclusions regarding past studies on civil war. Generally, the results are consistent with Fearon and Laitin's initial analysis; however, a few notable exceptions might suggest that the causes of civil war change over time. For instance, a noncontiguous territory was found to be insignificant in Fearon and Laitin's original model, but is positive and significant in each of the models limited to the 1980-1999 period. This same test limited to an earlier period (1945-1979) concurs with the original model, which suggests that, over time, having a noncontiguous territory increased the probability of civil war. This may suggest that as the world has become more integrated, states have become better at preventing civil wars within neighboring countries, which has been suggested recently by Barbieri and Reuveny (2005). Further, the positive and significant coefficient for oil exporter and instability in the authors' original model fails to attain significance in each of the subsequent models. Again, the earlier sample concurs with Fearon and Laitin's original model, indicating that the effect of these variables has decreased as time progressed. These contrasting findings suggest that civil war researchers might focus on how the effects of variables might change over time.

Several issues regarding the data and methods used above should be addressed. First, one should note the connection between the theory presented and the measures used to test the hypotheses empirically. The educational expenditures and primary enrollment variables are meant to test a direct and explicit link between education, grievances, and civil war. Unlike the first set of education variables, the measures for secondary enrollment, postsecondary enrollment, and literacy rates require the use of some unobserved mechanism to connect the concepts with the 
data. It is argued that higher levels of adult education should increase a feeling of social cohesion, decrease one's willingness to join rebel organizations, or promote alternatives to violence as a means to express discontent. These unobserved causal mechanisms are then linked to the probability of civil war onset. While these links are well founded in the social science literature, because they are unobserved, the conclusion that adult education should lead to a decrease in the probability of civil war, as well as the policy advice given above, is open to alternative theories and should be viewed with some caution. Future research will hopefully be able to provide a more explicit linkage between education, stability, and civil war onset. At this point, the analysis pushes well beyond macro-level variables such as GDP/ capita, which have consumed the bulk of empirical tests from past literature.

The second potential problem lies in complications due to endogeneity between civil war and the education variables. It is possible that education enrollment drops as a civil war approaches because people flee their homes in anticipation of fighting. Likewise, expenditures may drop before an insurgency as the government diverts resources from social expenditures to the military in order to defend itself. This issue is dealt with in the models by lagging the education variables at $t-1$. However, it is possible that problems with reverse causality appear before $t-1$. Following Smith and Blundell (1986), a two-stage model is run to test for endogeneity. In the first stage, the potential endogenous variables (education variables) are predicted using Stasavage's (2005) primary independent variables. ${ }^{12}$ The residuals from the first stage are then included in the second stage, which is Fearon and Laitin's (2003) base model plus the education variables (run separately). For each of the education variables, the null hypothesis that these residuals should have no explanatory power could not be rejected, providing strong support for the exogeneity of the education variables. ${ }^{13}$

A third possible criticism of the statistical analysis lies in the notion that wealth may be driving the significant findings for the education variables. This speaks to Sambanis' (2004a:266) argument against the assumption of unit homogeneity in large-N statistical studies. That is, the risk of civil war may not be spread evenly across countries. As we know, wealthy countries seldom experience civil wars (Sambanis 2001; Fearon and Laitin 2003; Collier and Hoeffler 2004). Further, wealthy countries generally have the strongest systems of education because they are more stable and simply have more money to spend. Therefore, by including wealthy countries (where civil war is extremely rare) in the population, the conclusion that high enrollment and equitable education expenditures prevents civil war might be spurious. Two analyses were run to check for this possible problem. The first and most obvious is that the education variables remain significant when controlling for per capita income. For a more nuanced test, the data were broken into (1) high and low wealth based on the mean income per capita and (2) quintiles based on income per capita. Separating the data in this manner effectively drops the wealthy countries that rarely experience civil war and are apt to have strong systems of education, which may then lead to a spurious conclusion that education prevents civil war.

Table 3 presents the coefficients for the education variables after the data were separated into samples based on income. The first column shows the coefficients for the original regressions reported in Tables 1 and 2. The second and third columns

\footnotetext{
${ }^{12}$ Stasavage (2005) examines how electoral competition influences public spending on education in African states. His original model includes multiparty competition, an election year dummy, GDP/capita $(\log )$, aid as a percentage of GDP, percent rural population, and percent of the population under the age of 15 , to predict various indicators of education spending.

${ }^{13}$ Primary enrollment $\chi^{2}=0.870, p=.351$; education expenditures $\chi^{2}=1.86, p=.173$; secondary male enrollment $\chi^{2}=1.24, p=.266$; secondary enrollment $\chi^{2}=0.727, p=.394$; university enrollment $\chi^{2}=0.322$, $p=.570$; adult literacy rate $\chi^{2}=0.190, p=.663$.
} 
TABLE 3. Coefficients for Education Variables Separated by Wealth

\begin{tabular}{ccccccccc}
\hline & $\begin{array}{c}\text { Original } \\
\text { Coefficient }\end{array}$ & $\begin{array}{c}\text { Below } \\
\text { Mean }\end{array}$ & $\begin{array}{c}\text { Above } \\
\text { Mean }\end{array}$ & $\begin{array}{c}\text { Lowest } \\
\text { Quintile }\end{array}$ & $\begin{array}{c}\text { Second } \\
\text { Quintile }\end{array}$ & $\begin{array}{c}\text { Third } \\
\text { Quintile }\end{array}$ & $\begin{array}{c}\text { Fourth } \\
\text { Quintile }\end{array}$ & $\begin{array}{c}\text { Highest } \\
\text { Quintile }\end{array}$ \\
\hline Primary & $-0.029^{* * *}$ & $-0.025^{* * * *}$ & -3.27 & $-0.027^{*}$ & -0.021 & -0.012 & -0.111 & - \\
enrollment & $(0.010)$ & $(0.006)$ & $(410.5)$ & $(0.011)$ & $(0.015)$ & $(0.022)$ & $(0.122)$ & - \\
Education & -0.132 & $-0.214^{*}$ & 54.9 & 0.081 & $-0.566^{* * *}$ & $-0.449^{*}$ & -2.06 & - \\
expenditure & $(0.102)$ & $(0.088)$ & $(4520.7)$ & $(0.143)$ & $(0.216)$ & $(0.207)$ & $(2.12)$ & \\
Secondary & $-0.014^{\dagger}$ & $-0.020^{* * *}$ & -11.9 & -0.009 & -0.014 & -0.018 & 0.073 & - \\
enrollment & $(0.008)$ & $(0.007)$ & $(439.3)$ & $(0.014)$ & $(0.016)$ & $(0.019)$ & $(0.058)$ & - \\
Secondary male & $-0.025^{* *}$ & $-0.029^{* * * *}$ & -12.2 & $-0.024^{\dagger}$ & $-0.033^{\dagger}$ & -0.017 & 0.075 & - \\
enrollment & $(0.008)$ & $(0.007)$ & $(545.8)$ & $(0.014)$ & $(0.017)$ & $(0.020)$ & $(0.061)$ & - \\
Postsecondary & 0.016 & $<0.001$ & -7.01 & 0.038 & 0.010 & -0.014 & $0.355^{\dagger}$ & - \\
enrollment & $(0.014)$ & $(0.014)$ & $(368.8)$ & $(0.025)$ & $(0.029)$ & $(0.036)$ & $(0.196)$ & \\
Adult literacy & $0.015^{\dagger}$ & $-0.019^{*}$ & 37.0 & -0.011 & -0.003 & -0.009 & 0.022 & - \\
Onset events & $(0.009)$ & $(0.008)$ & $(333.8)$ & $(0.013)$ & $(0.018)$ & $(0.028)$ & $(0.068)$ & 0 \\
Observation & 49 & 47 & 2 & 23 & 11 & 11 & 4 & 0 \\
\hline
\end{tabular}

Standard errors are in parentheses. Estimations performed using Stata 8.0.

${ }^{\dagger} p<.10,{ }^{*} p<.05, * * p<.01, * * * k<.001$ (two tailed). Only education variables are shown. The regressions are from the original model presented in Tables 2 and 3 minus the per capita income variable. Results from the whole models are available on the author's website. Estimates become unstable and meaningless in the higher echelons of income due to the low occurrence of civil wars among wealthy countries. For the same reason, the $N$ is not constant across quintiles because dummies that perfectly predict the dependent variable, along with their observations, are dropped from the analysis. There are no incidences of civil war in the highest quintile of per capita income.

split the data into two samples: above and below the mean. ${ }^{14}$ After rerunning the regressions for each of the samples, the conclusion that education prevents civil war remains strong. In fact, the education variables seem to have the strongest effect in the poorest countries, which supports the notion that education has a pacifying effect independent of wealth. This relationship holds for primary enrollment in the poorest group after the observations are broken into quintiles. Interestingly, the coefficients for educational expenditures are negative and significant in the second and third quintiles, while primary enrollment is not. This suggests that increasing primary enrollment in the poorest countries will have a pacifying effect on civil war while increases in aggregate spending, no matter where the money is directed, will have the same effect in more wealthy countries. Beyond the grievance variables, we see that the coefficients for adult literacy, which are significant in the original table, fail to attain significance in any of the quintiles. This is likely due to two factors. First, the decreased sample size has the effect of raising the standard errors, which makes it more difficult to find significance. Second, the effect of these variables is spread across all quintiles with borderline significance in each. Dividing the data further, into deciles perhaps, would likely identify exactly which group pushes the overall coefficient over the 0.05 threshold, but would offer little in the way of aiding our understanding of the causes of civil war. At any rate, the purpose of Table 3 was to see whether poverty alone was driving the results in response to Sambanis' (2004a:266) unit homogeneity argument, which the table adequately shows not to be the case.

An additional (and somewhat surprising) piece of information from Table 3 is seen in the positive and significant coefficient for postsecondary enrollment in the fourth quintile. According to these data, having high university enrollment in wealthy societies actually increases the probability of civil war onset. Past research

\footnotetext{
${ }^{14}$ The mean for this sample is 4.4. The mean group below includes 1965 of the 2,904 country-years (68\%). Results were similar using median (2.60), although primary enrollment and secondary enrollment became significant in the above median group.
} 
TABle 4. Effect of Health Provisions on the Probability of Civil War Onset

\begin{tabular}{|c|c|c|}
\hline & Model 1 & Model 2 \\
\hline Measles Immunity & $\begin{array}{r}-0.016^{*} \\
(0.007)\end{array}$ & \\
\hline DPT Immunity & & $\begin{array}{r}-0.013^{\dagger} \\
(0.008)\end{array}$ \\
\hline Prior war & $\begin{array}{r}-1.20 * * \\
(0.415)\end{array}$ & $\begin{array}{r}-1.24^{* * *} \\
(0.424)\end{array}$ \\
\hline Income/capita & $\begin{array}{c}-0.317^{* * *} \\
(0.108)\end{array}$ & $\begin{array}{c}-0.309 * * \\
(0.109)\end{array}$ \\
\hline Population $^{\ddagger}$ & $\begin{array}{c}0.226^{*} \\
(0.113)\end{array}$ & $\begin{array}{c}0.225^{*} \\
(0.113)\end{array}$ \\
\hline Percent mountainous ${ }^{\ddagger}$ & $\begin{array}{c}0.144 \\
(0.113)\end{array}$ & $\begin{array}{c}0.158 \\
(0.113)\end{array}$ \\
\hline Noncontiguous state & $\begin{array}{c}0.793^{\dagger} \\
(0.460)\end{array}$ & $\begin{array}{c}0.895^{*} \\
(0.457)\end{array}$ \\
\hline Oil exporter & $\begin{array}{c}0.179 \\
(0.411)\end{array}$ & $\begin{array}{c}0.098 \\
(0.416)\end{array}$ \\
\hline New state & $\begin{array}{c}2.36^{* * * * * *} \\
(0.561)\end{array}$ & $\begin{array}{c}2.35 * * * * \\
(0.564)\end{array}$ \\
\hline Instability & $\begin{array}{c}0.205 \\
(0.368)\end{array}$ & $\begin{array}{c}0.200 \\
(0.368)\end{array}$ \\
\hline Anocracy & $\begin{array}{l}1.10^{\text {***** }} \\
(0.335)\end{array}$ & $\begin{array}{c}1.11^{\text {****** }} \\
(0.337)\end{array}$ \\
\hline Constant & $\begin{array}{c}-5.22^{* * * * *} \\
(1.12)\end{array}$ & $\begin{array}{r}-5.38^{* * * * *} \\
(0.1 .12)\end{array}$ \\
\hline Onset events & 49 & 49 \\
\hline Observations & 2,744 & 2,904 \\
\hline
\end{tabular}

Note: Standard errors are in parentheses. Estimations performed using Stata 8.0.

${ }^{\dagger} p<.10, * p<.05, * * p<.01, * * * p<.001$ (two tailed).

${ }^{\ddagger}$ Values are logged.

Model 1, Immunization, measles (\% of children ages 12-23 months), lagged $t-1$; Model 2: Immunization, DPT (\% of children ages 12-23 months), lagged $t-1$.

from Kuran (1989) has found similar results when examining the roots of protest. These data show the possibility that protests begun by university students may turn protests into all-out rebellion in wealthy countries, which supports the first counterargument presented in the theoretical section and provides an interesting avenue for future research. This possibility is examined further in the next section.

\section{Extending the Analysis}

The hypotheses and tests presented thus far deal specifically with the effect of education on civil war. Several additional assertions made in the theoretical section can also be examined empirically. First, the grievance argument suggests that the government can use educational expenditures to signal that it is sensitive to the needs of the population. If government investment in essential services for the public is indeed linked to grievances and civil conflict, then we should see the same results for noneducation variables. This possibility is tested by including World Bank data on child immunizations to capture how well the government is providing basic health necessities. ${ }^{15}$ As we can see in Table 4, the results show the same

\footnotetext{
${ }^{15}$ Alternative measures, such as public expenditures on health and infant mortality rates, could not be used due to high amounts of missing data (94\% and $76 \%$ missing, respectively).
} 
TABLE 5. Effect of Education on Three Levels of Domestic Conflict

\begin{tabular}{|c|c|c|c|}
\hline & Protest Activity & Low-level Rebellion & Civil War ${ }^{\ddagger}$ \\
\hline Primary enrollment & $\begin{array}{c}0.004 \\
(0.003)\end{array}$ & $\begin{array}{r}-0.005 \\
(0.003)\end{array}$ & $\begin{array}{c}-0.029 * * * \\
(0.009)\end{array}$ \\
\hline Education expenditures & $\begin{array}{r}-0.014 \\
(0.040)\end{array}$ & $\begin{array}{c}-0.128^{* *} \\
(0.044)\end{array}$ & $\begin{array}{r}-0.184^{\dagger} \\
(0.103)\end{array}$ \\
\hline Secondary enrollment & $\begin{array}{c}0.003 \\
(0.003)\end{array}$ & $\begin{array}{r}-0.005 \\
(0.003)\end{array}$ & $\begin{array}{r}-0.014^{\dagger} \\
(0.007)\end{array}$ \\
\hline Secondary male enrollment & $\begin{array}{c}0.001 \\
(0.003)\end{array}$ & $\begin{array}{r}-0.006^{\dagger} \\
(0.004)\end{array}$ & $\begin{array}{c}-0.024^{* * *} \\
(0.008)\end{array}$ \\
\hline Postsecondary enrollment & $\begin{array}{c}0.007 \\
(0.007)\end{array}$ & $\begin{array}{r}-0.004 \\
(0.006)\end{array}$ & $\begin{array}{c}0.014 \\
(0.014)\end{array}$ \\
\hline Adult literacy & $\begin{array}{r}0.010^{*} \\
(0.004)\end{array}$ & $\begin{array}{c}-0.017^{* *} \\
(0.005)\end{array}$ & $\begin{array}{r}-0.015^{\dagger} \\
(0.008)\end{array}$ \\
\hline
\end{tabular}

${ }^{\dagger} p<.10, * p<.05,{ }^{* *} p<.01$ (two tailed). Controls are the same as those used for Tables $2-4$. The controls are not shown in order to save space. Peace years and splines are used to control for autocorrelation (Beck, Katz, and Tucker 1998).

${ }^{\ddagger}$ Results for "Civil War" are identical to those presented in Tables 1 and 2. Standard errors are in parentheses. Estimations performed using Stata 8.0.

negative and significant effect for each health measure on the probability of civil war onset, providing strong support for the grievance theory.

Next, the theory and analyses thus far have focused exclusively on the effect of education on civil wars, where the violence threshold is set very high. It is possible that education also affects lower levels of violence. Further, the relationships may not be as straightforward as we might expect. For instance, earlier it was suggested that while university students are less likely to begin a civil war, they may be more likely to engage in low-level protest. Thus, examining the effect of education on lower levels of domestic conflict will provide at least an avenue for future theoretical development. The Minorities at Risk (MAR) data set from MARGene provides a useful source of data for these tests (Bennett and Davenport, 2003). Following Regan and Norton (2005), the education variables are tested on two new dependent variables: protest and low-level rebellion. Protest is a dummy variable coded 1 if the maximum country-year value of protest takes on any nonzero value from MAR's "PROT" measure. These protest activities include "verbal opposition" at the low end and "large-scale demonstrations" at the high end. Similarly, rebellion is a more violent measure of protest, coded 1 if the MAR's "REB" variable takes on any nonzero value. ${ }^{16}$ These activities include "political banditry" at the low end and "small-scale guerrilla activity" at the high end. ${ }^{17}$ These data range from 1985 through 1999, totaling 1,617 country-year observations. The effect of education on these two new dependent variables is tested with the same control variables as before, which are dropped from the table to save space. The results from the previous analyses are inserted into Table 5 for easy comparison with the effect of education on increasing levels of antigovernment activity.

As we can see from Table 5, the pacifying effect of education on civil war does not necessarily hold for lower levels of domestic unrest. The variables for primary enrollment and secondary enrollment are significant only for civil war. Education expenditures and secondary male enrollment have a pacifying effect on both civil war and low-level rebellion, but have no effect on protest activity.

\footnotetext{
${ }^{16}$ See Regan and Norton (2005:327) for a more thorough description of how these variables are constructed.

${ }^{17}$ Following Regan and Norton (2005), three measures at the highest end of this scale (intermediate guerrilla activity, large-scale guerrilla activity, and protracted civil war) are not included in this measure in order to keep "lowlevel rebellion" distinct from "civil war."
} 
Strangely, postsecondary enrollment seems to have no effect on domestic unrest, no matter what level. Again, this is likely due to the high correlation between this measure and wealth, making it difficult to explain variance in the dependent variable with one measure over the other. Perhaps, the most interesting result from Table 5 is found for the adult literacy variable. According to these data, as a population becomes more educated, it is more likely to protest and less likely to start violent rebellions, which is what we might have expected for the postsecondary enrollment variable. This suggests that a large university enrollment is not enough to challenge the government; rather, some larger critical mass of adults is needed to spark a measurable protest. This finding also provides support for the opportunity argument. That is, educated people are willing (and perhaps better able) to protest against the government; however, they are unwilling to sacrifice their lives for their cause. Overall, the analyses presented in Table 5 strongly support the argument that not all forms of domestic violence should be treated equally, whether examining education or other predictors of internal violence. The strongest findings from this paper hold primarily for the highest level of violence, civil wars, leaving future studies to examine factors contributing to lower levels of civil conflict.

\section{Conclusion and Implications}

The goal of this paper was to examine how education might affect civil war based on two arguments. First, investment in education is a means by which a government can signal to the population that it is trying to improve their lives. The result of this investment, therefore, should be to lower grievances that could foment rebellion in society. Two indicators, expenditures allocated to education and primary enrollment, were used to test this argument. Results from the logistic regression of a panel of 160 countries from 1980 through 1999 indicate that educational investment indeed lowers the probability of civil war, especially when it is distributed equitably. The signaling argument was reinforced with significant findings for the availability of basic health needs.

The second half of the theory claimed that education for both young adults and adults could lower civil war through two mechanisms. First, rebels face higher opportunity costs when young men are attending school. Second, an educated population is more likely to have the capacity to express its grievances through peaceful means. Additionally, an educated society understands the difficult job of governing during times of poverty and is more apt to give the government leeway to make social and economic reforms that may hurt in the short term. In order to test the second half of the theory, indicators of secondary enrollment, postsecondary enrollment, and literacy rates were examined. Results strongly support the notion that secondary enrollment, male secondary enrollment, and literacy rates decrease the probability of war. Postsecondary enrollment rates provided no extra explanatory power to the model. In a more nuanced test, results showed that the majority of education variables affect only high levels of antigovernment violence, as they fail to attain standard levels of significance when protest and low-level rebellion are used as dependent variables. Levels of adult literacy were found to both increase low-level protest while decreasing more violent levels of rebellion. Overall, the results support both the grievance and stability explanations for the pacifying effect of education on civil war.

This study has important implications for the future of civil war research and international relations research in general. First, this study has demonstrated the usefulness of the Amelia data imputation program. By imputing missing data, this study was better able to provide a system-wide test of all countries, which avoids possible bias caused by deleting cases in a systematic manner. More importantly, many scholars in the conflict community have called for civil war research to move beyond the greed versus grievance debate, which relies primarily on economic 
variables. This study has shown how we can effectively move beyond this dichotomy to identify specific factors that may lead to or prevent civil war.

This study also suggests important implications for the international policy community. While other significant predictors of civil war, such as mountainous terrain and per capita income, are impossible or very difficult to change, education is an area that can be changed relatively easily with increased investment and policy advice. For example, based on the findings that increased primary enrollment reduces the probability of civil war, an increase in aid specifically for primary education should result in a decrease in civil war. Further, special efforts should be made to retain young men in secondary schools, which would have the effect of raising the recruitment costs of rebels and, thus, lower the probability of civil war. If our ultimate goal is to slow down and possibly prevent civil war, then identification of causal factors such as education should be a primary concern for current researchers studying civil war. This study serves as an important step in that direction.

\section{References}

Addison, Tony, and Mansoob Murshed. (2003) Debt Relief and Civil War. Journal of Peace Research 40:159-176.

Adeola, Francis. (1996) Military Expenditures, Health, and Education: Bedfellows or Antagonists in Third World Development? Armed Forces and Society 22:441-467.

Almond, Gabriel, Powell Bingham Jr., Kaare Strom, and Russell J. Dalton. (2004) Comparative Politics: A Theoretical Framework. $4^{\text {th }}$ edition. Reading, MA: Addison Wesley Longman.

Amamio, May C. (2004) The Role of Peace Education in Preventing Conflict. UNESCO First Committee, session VI. Available from artilect.org/altman/reports.html (Accessed 8 May 2005)

Aoki, Aya, Barbara Bruns, Michael Drabble, Mmantsetsa Marope, Alain Mingat, Peter Moock, Patrick Murphy, Pierella Paci, Harry Patrinos, Jee-Peng Tan, Christopher Thomas, Carolyn Winter, And Hongyu Yang. (2002) Chapter 19: Education in PRSP Education. Available from http://www.worldbank.org/poverty/strategies/index.htm (Accessed March 16, 2005)

Arthur, Marie Jose. (1998) Mozambique: Women in the Armed Struggle. In Southern Africa in Transition: A Gendered Perspective, edited by P. McFadden. Harare: Sapes.

Awofeso, Niji, Jan Ritchie, and Pieter Degeling. (2003) The Almajiri Heritage and the Threat of Non-State Terrorism in Northern Nigeria-Lessons from Central Asia and Pakistan. Studies in Conflict and Terrorism 26:311-325.

Azam, Jean-Paul, and Anke Hoeffler. (2002) Violence Against Civilians in Civil Wars: Looting or Terror? Journal of Peace Research 39:461-485.

Barbieri, Katherine, AND Rafael Reuveny. (2005) Economic Globalization and Civil War. Journal of Politics 67:1228-1247.

Barro, Robert, and Jong Wha Lee. (1996) International Measures of Schooling Years and Schooling Quality. AER, Papers and Proceedings 86:218-223.

Beck, Neal, Jonathan Katz, and Richard Tucker. (1998) Taking Time Seriously: Time-SeriesCross-Section Analysis with a Binary Dependent Variable. American Journal of Political Science 42:1260-1288.

Belloni, Roberto. (2001) Civil Society and Peacebuilding in Bosnia and Herzegovina. Journal of Peace Research 38:163-180.

Bennett, D. Scott, and Christian Davenport. (2003) MARGene v.1.0. Available from http:www. edicm.umd.edu/inscr/mar/maegene.htm.

Birdsall, Nancy. (1998) The People's Asset: Education in Latin America. Paper presented at the Thirtieth Anniversary Conference, Special Program for Urban and Regional Studies of Developing Areas. Cambridge, MA: Massachusetts Institute of Technology.

Birdsall, Nancy, Juan Luis London, and Lesley O’Connell. (1998) Education in Latin America: Demand and Distribution are Factors that Matter, CEPAL Review 66, December 1998.

Brady, Henry, Sidney Verba, and Kay Schlozman. (1995) Beyond SES: A Resource Model of Political Participation. American Political Science Review 89:271-294.

Breidlid, Anders. (2005) Education in the Sudan: The Privileging of an Islamic Discourse. Compare 35:247-263.

Brown, David, and Wendy Hunter. (2004) Democracy and Human Capital Formation: Education Spending in Latin America, 1980 to 1997. Comparative Political Studies 37:842-864. 
Cairns, Edmund. (1997) A Safer Future: Reducing the Human Cost of War. Oxford, U.K.: Oxfam Publications.

Caprioli, Mary. (2005) Primed for Violence: The Role of Gender Inequality in Predicting Internal Conflict. International Studies Quarterly 49:161-178.

Collier, Paul. (2000) Economic Causes of Civil Conflict and Their Implications for Policy. World Bank Development Research Group, June 15, 2000.

Collier, Paul, Lani Elliott, Havard Hegre, Anke Hoeffler, Marta Reynal-Querol, and Nicholas Sambanis. (2003) Breaking the Conflict Trap: Civil War and Development Policy. Washington, DC: The International Bank for Reconstruction and Development/The World Bank.

Collier, Paul, And Anke Hoeffler. (2004) Greed and Grievance in Civil War. Oxford Economic Papers 56:563-595.

Collier, Paul, Anke Hoeffler, And Mans Soderbom. (2004) On the Duration of Civil War. Journal of Peace Research 41:253-273.

Countrystudies. US. (2005) Federal Research Division of the Library of Congress Country Studies/ Area Handbook Series. U.S. Department of the Army. Available from http://countrystudies.us. (Accessed August 11, 2005)

Critchley, W. Harriet, and Terry Terriff. (1993) Environment and Security. In Security Studies for the 1990's, edited by Richard Schultz, Roy Godson and Ted Greenwood. Washington, DC: Brassey's.

Dalrymple, William. (2005) Inside the Madrassas. The New York Review of Books 52(19). Available from http://www.nybooks.com/.

Deng, Francis M. (2001) Sudan-Civil War and Genocide: Disappearing Christians of the Middle East. Middle East Quarterly. Available from http://www.meforum.org/article/22. (Accessed December 10, 2005)

ECKSTEIn, Harry. (1964) Introduction: Toward the Theoretical Study of Internal War. In Internal War, edited by Harry Eckstein. New York: Free Press.

Elbadawi, Ibrahim, and Nicholas Sambanis. (2000) Why Are There So Many Civil Wars in Africa? Understanding and Preventing Violent Conflict. Journal of African Economies 9:244-269.

Elbadawi, Ibrahim, and Nicholas Sambanis. (2002) How Much War Will We See? Explaining the Prevalence of Civil War. Journal of Conflict Resolution 46:307-334.

Fearon, D. James, And D. David Laitin. (2003) Ethnicity, Insurgency, and Civil War. American Political Science Review 97:75-90.

Ferranti, David, Guillermo Perry, Francisco Ferreira, and Michael Walton. (2004) Inequality in Latin America: Breaking with History? Washington, DC: The World Bank.

Ghobarah, Hazem A., Paul Huth, and Bruce Russett. (2003) Civil Wars Kill and Maim People-Long after the Shooting Stops. American Political Science Review 97:189-202.

Gleditsch, Nils Petter, Peter Wallensteen, Mikael Eriksson, Margareta Sollenberg, and Havard Strand. (2002) Armed Conflict 1946-2001: A New Dataset. Journal of Peace Research 39:615-637.

Glickman, Harvey. (2000) Islamism in Sudan's Civil War. Orbis 44:267-282.

Granato, Jim, Ronald Inglehart, and David Leblang. (1996) The Effect of Cultural Values on Economic Development: Theory, Hypotheses, and Some Empirical Tests. American Journal of Political Science 40:607-631.

Grossman, Herschel I. (1991) A General Equilibrium Model of Insurrections. American Economic Review 81:912-921.

Grossman, Herschel I. (1999) Kleptocracy and Revolutions. Oxford Economic Papers 51:267-283.

Guha-Sapir, Debbie, and Willem Van Panhuis. (2002) Mortality Risks in Recent Civil Conflicts: A Comparative Analysis. Brussels: Centre for Research on the Epidemiology of Disasters.

Hegre, Havard, Tanja Ellingsen, Scott Gates, and Nils Petter Gleditsch. (2001) Toward a Democratic Civil Peace? Democracy, Political Change, and Civil War, 1816-1992. American Political Science Review 95:33-48.

Heyneman, Stephen P. (2003) Education, Social Cohesion, and the Future Role of International Organizations. Peabody Journal of Education 78:25-38.

Hoeffler, Anke, and Marta Reynal-Querol. (2003) Measuring the Cost of Conflict. Oxford, U.K.: Oxford University. Available from http://users.ox.ac.uk/ ball0144. (Accessed March 31, 2005).

Hojman, David. (1996) Poverty and Inequality in Chile: Are Democratic Politics and Neoliberal Economics Good for You? Journal of Inter-American Studies and World Affairs 38:73-96.

Honaker, James, Anne Joseph, Gary King, Kenneth Scheve, and Naunihal Singh. (2001) Amelia: $A$ Program for Missing Data (Windows version). Cambridge, MA: Harvard University. Available from http://GKing.Harvard.edu/ (Accessed August 4, 2005). 
Hunter, Wendy, and David S. Brown. (2000) World Bank Directives, Domestic Interests, and the Politics of Human Capital Investment in Latin America. Comparative Political Studies 33: $113-143$.

Inter-American Development Bank. (1999) Facing up to Inequality in Latin America. Washington, DC: InterAmerican Development Bank.

Keen, David. (2005) Liberalization and Conflict. International Political Science Review 26:73-89.

King, Gary, James Honaker, Anne Joseph, and Kenneth Scheve. (2001) Analyzing Incomplete Political Science Data: An Alternative Algorithm for Multiple Imputation. American Political Science Review 95:49-69.

Knight, Mark, and Alpaslan Ozerdem. (2004) Guns, Camps and Cash: Disarmament, Demobilization and Reinsertion of Former Combatants in Transitions from War to Peace. Journal of Peace Research 41:499-516.

Kriger, Norma J. (1992) Zimbabwe's Guerrilla War: Peasant Voices. Cambridge: Cambridge University Press.

Kuran, Timur. (1989) Sparks and Prairie Fires: A Theory of Unanticipated Political Revolution. Public Choice 61:41-74.

Lai, Brian, and Clayton Thyne. (forthcoming) The Effect of Civil War on Education, 1980-1997. Journal of Peace Research 44(3).

Lipset, Seymour Martin. (1959) Some Social Requisites of Democracy: Economic Development and Political Legitimacy. American Political Science Review 53:69-105.

Londono, Juan Luis. (1996) Poverty, Inequality, and Human Capital Development in Latin America, 19502025. Washington, DC: World Bank.

López-Acevedo, GLAdys. (2001) Evolution of Earning and Rates of Returns to Education in Mexico. Washington, DC: The World Bank.

Mayssam, Ali. (1995) The Road to Recovery. Harvard International Review 17(4):70-74.

MELANDER, ERIK. (2005) Gender Equality and Intrastate Armed Conflict. International Studies Quarterly 49:695-714.

Mohammed, Nadir. (1999) Civil Wars and Military Expenditures: A Note. Presented at the World Bank's Development Economic Research Group (DECRG) conference on "Civil Conflict, Crime and Violence," February 22-23, 1999 Washington, DC: World Bank.

Moore, Will H. (1995) Action-Reaction or Rational Expectations? Reciprocity and the DomesticInternational Conflict Nexus During the 'Rhodesia Problem.' Journal of Conflict Resolution 39:129-167.

Murdoch, James, and Todd Sandler. (2004) Civil Wars and Economic Growth: Spatial Dispersion. American Journal of Political Science 48:138-151.

Murshed, Mansoob. (2002) Conflict, Civil War and Underdevelopment: An Introduction. Journal of Peace Research 39:287-393.

Paul, Jean Jacques, and Laurence Wolff. (1996) The Economics of Higher Education. In Opportunity foregone: Education in Brazil, edited by Nancy Birdsall and Richard Sabot. Washington, DC: InterAmerican Development Bank.

Perez, Orlando J. (2003) Democratic Legitimacy and Public Insecurity: Crime and Democracy in El Salvador and Guatemala. Political Science Quarterly 118:627-644.

Peters, Krijn, and Paul Richards. (1998) 'Why We Fight': Voices of Youth Combatants in Sierra Leone. Africa 68:183-210.

Quinn, Kevin, Michael Hechter, And Erik Wibbels. (2003) Ethnicity, Insurgency, and Civil War Revisited, Mimeo, Center for Statistics and Social Sciences, University of Washington, Seattle. Available from http://www.yale.edu/ycias/ocvprogram/Quinn_\&_Hechter.pdf. (Accessed December 4, 2005)

Regan, Patrick M., and Daniel Norton. (2005) Greed, Grievance, and Mobilization in Civil Wars. Journal of Conflict Resolution 49:319-336.

ReynoldS, LlOyd. (1996) Some Sources of Income Inequality in Latin America. Journal of InterAmerican Studies and World Affairs 38:39-46.

Richards, Paul. (2003) Are there Common Causes to Recent West African Insurgencies? Economic Opportunities and the War Economy. Organisation for Economic Co-operation and Development. Available from http://www.oecd.org/dataoecd/18/38/33,905,612.pdf. (Accessed December $13,2005)$

Ross, Michael. (2004) What Do We Know About Natural Resources and Civil War? Journal of Peace Research 41:337-356.

Saint-Paul, Gilles, And Thierry Verdier. (1992) Education, Democracy and Growth. CEPR Discussion Paper Abstracts. Available from http://www.cepr.org/pubs/dps/DP613.asp. (Accessed May 27, 2005) 
Sambanis, Nicholas. (2001) Do Ethnic and Non-Ethnic Civil Wars Have the Same Causes? A Theoretical and Empirical Inquiry. Journal of Conflict Resolution 45:259-282.

Sambanis, Nicholas. (2004a) Expanding Economic Models of Civil War Using Case Studies. Perspectives on Politics 2:259-279.

Sambanis, Nicholas. (2004b) What Is a Civil War? Conceptual and Empirical Complexities of an Operational Definition. Journal of Conflict Resolution 48:814-858.

Sargent, Lyman. (1996) Contemporary Political Ideologies: A Comparative Analysis. USA: Wadsworth Publishing Company.

Sen, Amartya. (1973) On Economic Inequality. Oxford, U.K. Clarendon Press.

Singer, J. David, and Melvin Small. (1994) Correlates of War Project: International and Civil War Data, 1816-1992. Computer File. ADDRESS: CISER. Access Year, 2004

SirleAf, Ellen J. (1991) The Causes and Consequences of the Liberian Civil War. Harvard International Review 13:32-36.

Smith, Richard J., ANd Richard W. Blundell. (1986) An Exogeneity Test for a Simultaneous Equation Tobit Model with and Application to Labor Supply. Econometrica 54(3):679-685.

Stasavage, David. (2005) Democracy and Education Spending in Africa. American Journal of Political Science 49:343-358.

Stern, Jessica. (2000) Pakistan's Jihad Culture. Foreign Affairs 79:115-126.

UNESCO InSTITUTE FOR STATISTICS. (2004) Available from http://www.uis.unesco.org. (Accessed July 21, 2004)

United Nations Convention on the Rights of the Child. (1989) UN General Assembly, Document A/RES/44/25 (December 12, 1989). Available from http://www.hrweb.org/legal/child.html (Accessed June 15, 2005)

Weinstein, Jeremy M. (2005) Resources and the Information Problem in Rebel Recruitment. Journal of Conflict Resolution 49:598-624.

Woolcock, Michael, William Easterly, and Joe Ritzen. (2000) On 'Good' Politicians and 'Bad' Policies: Social Cohesion, Institutions, and Growth. Paper 2448, World Bank, Country Economics Department.

World Development IndicAtors. (WDI) methodology. (2004) Available from http://www.worldbank. org/data/aboutdata/working-meth.html\#definitions. (Accessed December 26, 2004)

World Development Indicators. (WDI) Online. (2004) The World Bank Group. Available from http://80-devdata.worldbank.org.proxy.lib.uiowa.edu/dataonline. (Accessed December 26, 2004) 